\title{
Article \\ Olive Cake Powder as Functional Ingredient to Improve the Quality of Gluten-Free Breadsticks
}

\author{
Giuditta de Gennaro, Graziana Difonzo *(D), Carmine Summo (D), Antonella Pasqualone (D) and Francesco Caponio (D)
}

check for

updates

Citation: de Gennaro, G.; Difonzo, G.; Summo, C.; Pasqualone, A.; Caponio, F. Olive Cake Powder as Functional Ingredient to Improve the Quality of Gluten-Free Breadsticks. Foods 2022, 11, 552. https://doi.org/10.3390/ foods11040552

Received: 30 December 2021 Accepted: 12 February 2022 Published: 15 February 2022

Publisher's Note: MDPI stays neutral with regard to jurisdictional claims in published maps and institutional affiliations.

Copyright: (C) 2022 by the authors. Licensee MDPI, Basel, Switzerland. This article is an open access article distributed under the terms and conditions of the Creative Commons Attribution (CC BY) license (https:// creativecommons.org/licenses/by/ $4.0 /)$.
Department of Soil, Plant and Food Science (DISSPA), University of Bari Aldo Moro, Via Amendola, 165/a, I-70126 Bari, Italy; giuditta.degennaro@uniba.it (G.d.G.); carmine.summo@uniba.it (C.S.); antonella.pasqualone@uniba.it (A.P.); francesco.caponio@uniba.it (F.C.)

* Correspondence: graziana.difonzo@uniba.it

\begin{abstract}
The growing demand for high-quality gluten-free baked snacks has led researchers to test innovative ingredients. The aim of this work was to assess the feasibility of olive cake powder (OCP) to be used as a functional ingredient in gluten-free (GF) breadsticks. OCP was used by replacing 1, 2, and 3\% of maize flour into GF breadstick production (BS1, BS2, BS3, respectively), and their influence on nutritional, bioactive, textural, and sensorial properties was assessed and compared with a control sample (BSC). BS1, BS2, and BS3 showed a higher lipid, moisture, and ash content. BS2 and BS3

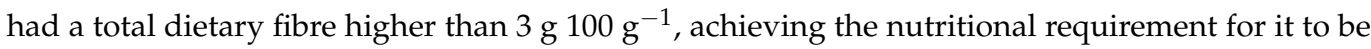
labelled as a "source of fibre". The increasing replacement of olive cake in the formulation resulted in progressively higher total phenol content and antioxidant activity for fortified GF breadsticks. The $L^{*}$ and $b^{*}$ values decreased in all enriched GF breadsticks when compared with the control, while hardness was the lowest in BS3. The volatile profile highlighted a significant reduction in aldehydes, markers of lipid oxidation, and Maillard products (Strecker aldehydes, pyrazines, furans, ketones) in BS1, BS2, and BS3 when compared with BSC. The sensory profile showed a strong influence of OCP addition on GF breadsticks for almost all the parameters considered, with a higher overall pleasantness score for BS2 and BS3.
\end{abstract}

Keywords: gluten-free; breadsticks; olive cake; dietary fibre; polyphenols; antioxidant activity; lipid oxidation; texture

\section{Introduction}

The gluten-free (GF) market is growing rapidly due to an indistinct adherence of consumers to a gluten-free diet [1]. Adherence to a GF diet is not limited to people who are intolerant to gluten, but is also observed by people who are not affected by gluten disorders who decide to follow it, believing that GF products are healthier, or simply following a trend of the moment [2]. However, several studies have focused attention onto the nutritional imbalance of GF cereal products [3-6]. From the comparison with their gluten-containing counterparts, GF products are richer in fats, mainly saturated, and carbohydrates, with a higher glycaemic index $[5,7,8]$, and they are poorer in protein, dietary fibre, minerals, and vitamins $[3-5,9,10]$.

The absence of gluten, beyond just negatively affecting the nutritional profile, has a strong influence on even the rheological, textural, and sensory properties, determining a relaxed dough that is difficult to handle, and a consequently crumbling texture, a poor colour, and a low satisfying taste and mouthfeel of baked products [11]. Indeed, gluten plays a fundamental role in formulating high-quality cereal-based goods: it is formed of proteins, mainly glutenin and gliadin, so that when fully hydrated they confer cohesive elastic and viscous properties to the dough, positively affecting the textural and sensory properties of baked foods [12,13].

GF cereal food deficiencies have led researchers to find alternative ingredients to improve their quality. Several ingredients have been tested, including starches [14,15], 
hydrocolloids [16,17], isolated protein or protein-rich ingredients [18-21], and dietary fibre, e.g., inulin, psyllium fibre, and resistant starch [15,22]. Among them, protein and dietary fibre addition allows us to meet the need for the nutritional and technological improvement, due to their functional properties [23-25]. However, alternatively to the use of the functional ingredients mentioned above, which have a high cost [26], vegetable by-products could represent a valuable and sustainable source of bioactive and functional compounds with technological properties [27-29]. Olive by-products seem to be very promising [30,31], and among them, olive cake obtained by a multi-phase decanter and constituted only by pulp and its vegetation water without traces of kernels [32], is an interesting source of dietary fibre, polyphenols, triterpenic acids, tocochromanols, and carotenoids [33-35]. Moreover, it shows a good mineral content and lipidic profile due to its richness in mono and polyunsaturated acids (oleic, linoleic, and linolenic acid) [36]. In the literature, there are several studies that have highlighted the health benefits related to a regular and appropriate ingestion of fibre [37-40] and phenolic compounds [41-43], which are also exploited as natural additives in foods, substituting chemical ones, due to their antioxidant and antimicrobials actions [44-46].

Some studies have been conducted on the exploitation of olive cake as a new functional ingredient in fortified cereal-based foods $[31,47,48]$, but no research has been carried out using olive cake powder as a new ingredient in gluten-free products. In this framework, the aim of this study was to use olive cake powder in the formulation of gluten-free breadsticks to improve their quality. In particular, olive cake was added at 1,2, and 3\% in substitution of maize flour into GF breadstick production, and the influence on the textural, sensory, and nutritional properties was evaluated.

\section{Materials and Methods}

\subsection{Gluten-Free Breadsticks Preparation}

Control GF breadsticks (BSC) were prepared using the following ingredients: rice flour $(41 \%)$, water $(35 \%)$, sunflower oil (11\%), maize flour $(9 \%)$, psyllium fibre $(2 \%)$, baking powder (1.5\%; disodium diphosphate, sodium hydrogen carbonate, maize starch), and salt $(0.5 \%)$. Olive cake powder (OCP)—prepared by lyophilizing (Lyophiliser Buchi, Switzerland, Lyovapor ${ }^{\mathrm{TM}} \mathrm{L}-200$ ) wet olive cake and subsequently grinding it - was utilised by replacing maize flour, which mainly affects the sensorial properties, in amounts of 1,2 , and $3 \%$ (BS1, BS2, and BS3, respectively). For the breadsticks' preparation, psyllium fibre was gradually added to water and oil and homogenised to facilitate the formation of a gel. The resulting gel was added to rice and maize flours, $\mathrm{OCP}$, salt, and baking powder previously mixed in a bowl. After $15 \mathrm{~min}$ of manual kneading, the doughs were hand-shaped to form breadsticks $9 \mathrm{~cm}$ long. Afterwards, the breadsticks were boiled in water for $2 \mathrm{~min}$ and let to dry for $5 \mathrm{~min}$ at room temperature to determine the starch gelatinisation and to obtain a more compact and cohesive structure of the breadsticks. Finally, the boiled breadsticks were baked in a forced-air convention oven (Smeg SI 850 RA-5 oven, Smeg S.p.A., Guastalla, Italy) at $200{ }^{\circ} \mathrm{C}$ for $27 \mathrm{~min}$ and cooled to room temperature. Three independent breadsticks productions were carried out.

\subsection{Proximate Composition}

Protein (total nitrogen $\times 6.25$ ), ash, and lipids content were determined using the AOAC methods 979.09, 923.03, and 945.38 F, respectively [49]. Moisture was determined by a moisture analyser (Mod. MAC 110/NP, Radwag Wagi Elektroniczne, Poland) at $105{ }^{\circ} \mathrm{C}$, until a constant weight. The total fibre content was determined by an enzymaticgravimetric process as described by the AOAC Official Method 991.43 [49]. The carbohydrate content was calculated as a difference. The analyses were carried out in triplicate.

\subsection{Extract Preparation}

The phenolic extraction was carried out following the procedure reported by Caponio et al. [50] with some modifications. An amount of $2 \mathrm{~mL}$ of hexane, to remove the 
oil phase, was added to $2 \mathrm{~g}$ of sample and $10 \mathrm{~mL}$ of methanol:water (80:20 $v / v)$. After stirring for $15 \mathrm{~min}$, samples were sonicated (Ultrasonic cleaner CP104, EIA) for $15 \mathrm{~min}$, then centrifugated at $10,000 \times \mathrm{g} \mathrm{min}^{-1}$ for $10 \mathrm{~min}$ at $24^{\circ} \mathrm{C}$ (Thermo Fisher Scientific, Osterodeam Harz, Germany). The supernatant was collected, while the pellet was subjected to two further extractions. The extracts were centrifugated at $8000 \times g \mathrm{~min}^{-1}$ for $2 \mathrm{~min}$ at $24{ }^{\circ} \mathrm{C}$. Then, the hydroalcoholic phases were filtered through a nylon filter (pore diameter $0.45 \mu \mathrm{m}$, Sigma, Ireland) within amber vial. A total of three extractions were carried out, following the procedure described above.

\subsubsection{Total Phenols and Antioxidant Activity of OCP and GF Breadsticks}

Total phenols content and antioxidant activity were determined spectrophotometrically, by the Folin-Ciocalteu method and ABTS (2, 2'-azinobis-3-ethylbenzothiazoline-6sulfonic acid) and DPPH (1,1-diphenyl-2-picrylhydrazyl)assays, respectively. An amount of $20 \mu \mathrm{L}$ of extract, properly diluted, was added to $980 \mu \mathrm{L}$ of MilliQ water and $100 \mu \mathrm{L}$ of Folin reagent. After 3 min of incubation, $800 \mu \mathrm{L}$ of $\mathrm{Na}_{2} \mathrm{CO}_{3}$ was added and kept in the dark for $1 \mathrm{~h}$. The absorbance was read at $720 \mathrm{~nm}$ using a Cary 60 spectrophotometer (Cernusco, Milan, Italy). The results were expressed as milligrams of gallic acid equivalents (GAE) per gram of product. As regards antioxidant activity, the DPPH (2,2-diphenyl-1-picrylhydrazyl) and ABTS assays were performed as reported by Difonzo et al. [51]. The results were expressed as micromolar Trolox equivalent (TE) $\mathrm{g}^{-1}$ dry weight. The determinations were carried out in triplicate.

\subsubsection{Total Tocopherols of OCP}

Tocopherols were determined using a reverse-phase, ultra-high-performance chromatographyfluorescence detector (RP-UHPLC-FLD). An amount of $0.02 \mathrm{~g}$ of sample was dissolved in $700 \mu \mathrm{L}$ of 2-propanol, then stirred and filtered. Then, $20 \mu \mathrm{L}$ was injected into a UHPLC system (Dionex Ultimate 3000 RSLC, Waltham, MA, USA) equipped with an HPG-3200 RS pump, WPS-3000 autosampler, TCC-3000 column compartment, and a FLD-3400 RS fluorescence detector. A Dionex Acclaim 120 C18 analytical column $(150 \times 3 \mathrm{~mm}$ i.d. $)$ with a particle size of $3 \mu \mathrm{m}$ (Thermo Scientific, Waltham, MA, USA) was used. Mobile phase consisted of a mixture of acetonitrile and methanol $(1: 1 v / v)$ at a constant flow rate of $1 \mathrm{~mL} \cdot \mathrm{min}^{-1}$ in isocratic elution mode. The FLD detector was set at an excitation wavelength of $295 \mathrm{~nm}$ and at an emission wavelength of $325 \mathrm{~nm}$. The quantification of tocopherols was performed by external calibration obtained with standard solutions of $\alpha$-tocopherols, and the results were expressed as $\mathrm{mg} \cdot \mathrm{kg}^{-1}$ of sample.

\subsection{Texture Analysis of GF Breadsticks}

The texture parameters (hardness and brittleness) of GF breadsticks were determined through a three-point bending test according to Conte et al. [52], providing some modifications. A texture analyser, Z1.0 TN (Zwick/Roell, Ulm, Germany), was equipped with a $1 \mathrm{KN}$ load cell. The breadsticks were placed in the middle of the support, setting the bars distance at $60 \mathrm{~mm}$ and the blade probe speed at $3 \mathrm{~mm} \mathrm{~s}^{-1}$. The maximum force required to break the breadstick $(\mathrm{N})$ and the distance crossed by the blade before breadsticks broke $(\mathrm{mm})$ were measured, which represent hardness and brittleness, respectively. The analysis was carried out in triplicate.

\subsection{Colour Evaluation}

The colorimetric analysis was carried out using a colorimeter CM-600d (Konica Minolta, Tokyo, Japan) supported by SpectraMagic NX software. Gluten-free breadsticks were ground to obtain a powder and placed in a specific vessel. Luminosity $\left(L^{*}\right)$, red index $\left(a^{*}\right)$, and yellow index $\left(b^{*}\right)$ were considered in accordance with the International Commission 
on Illumination (CIE). Three replicated analyses were carried out. Colour difference $(\Delta \mathrm{E})$ between control $(c)$ and fortified samples was calculated as follows:

$$
\Delta \mathrm{E}=\left[(L-L c)^{2}+(a-a c)^{2}+(b-b c)^{2}\right]^{1 / 2}
$$

\subsection{Volatile Compounds of GF Breadsticks}

Volatile compounds of GF breadsticks were analysed through headspace solid phase micro-extraction (HS-SPME), coupled with a gas chromatography/mass spectrometry as reported by Difonzo et al. [53]. In particular, $0.5 \mathrm{~g}$ grounded GF breadsticks were weighed in $12 \mathrm{~mL}$ vials and $150 \mu \mathrm{L}$ of 1-propanol was added as internal standard plus $4 \mathrm{~mL}$ of $\mathrm{NaCl}$ $(20 \% w / v)$ aqueous solution. Vials were sealed with aluminium crimps caps equipped with a butyl rubber septum. Before volatile compounds' extraction, vials were shaken for 2 min with a laboratory vortex to promote samples homogenisation. For the separation of volatile compounds, an Agilent 6850 gas-chromatograph equipped with an Agilent 5975 mass-spectrometer (Agilent Technologies Inc., Santa Clara, CA, USA) and an HP-Innowax (Agilent Technologies Inc., Santa Clara, CA, USA) polar capillary column $(60 \mathrm{~m}$ length $\times$ $0.25 \mathrm{~mm}$ i.d. $\times 0.25 \mu \mathrm{m}$ film thickness) was used. Volatiles were extracted by exposing a SPME fibre $75 \mu \mathrm{m}$ carboxen/polydimethylsiloxane (CAR/PDMS) (Supelco, Bellefonte, PA, USA) in the headspace of the vials at $40^{\circ} \mathrm{C}$ for $50 \mathrm{~min}$, then it was desorbed for $6 \mathrm{~min}$ in the injection port of the gas-chromatograph, operating in a split-less mode at $230{ }^{\circ} \mathrm{C}$ for $3.5 \mathrm{~min}$. The separation of volatile compounds was carried out following the current conditions: injector temperature, $250^{\circ} \mathrm{C}$; helium was used as a carrier gas with a flow of $1.5 \mathrm{~mL} \mathrm{~min}{ }^{-1}$. The oven temperature was held for $5 \mathrm{~min}$ at $35^{\circ} \mathrm{C}$, then increased by $5{ }^{\circ} \mathrm{C}$ $\min ^{-1}$ until it reached $50{ }^{\circ} \mathrm{C}$. This temperature was held constant for $5 \mathrm{~min}$, then raised to $210{ }^{\circ} \mathrm{C}$ at $5.5^{\circ} \mathrm{C} \mathrm{min}^{-1}$, and finally held constant at $210{ }^{\circ} \mathrm{C}$ for $5 \mathrm{~min}$. The mass detector was set at the following conditions: interface temperature $230{ }^{\circ} \mathrm{C}$, source temperature $230{ }^{\circ} \mathrm{C}$, ionisation energy $70 \mathrm{eV}$, and scan range 33-260 amu. The volatile compounds were quantified through the standardisation of the peak area of internal standard with the peak areas of the compounds of interests. The analyses were carried out in triplicate.

\subsection{Sensory Evaluation}

Sensory analysis was conducted by a semi-trained panel composed of eight panellists, chosen among professors, laboratory technicians, and researchers. The analysis was carried out according to the ethical guidelines of the Laboratory of Food Science and Technology of the Department of Plant, Soil and Food Science of University of Bari, Italy. A total of 10 descriptors were selected considering the product analysed and by-products added in the formulation: 3 descriptors for visual appearance (surface uniformity, surface colour, surface colour intensity); 1 descriptor for the odour (olive); 2 for texture perceived during tasting (hardness, brittleness); 4 for taste (salty, bitterness, astringent, oiliness). The perception intensity of the descriptors was assessed on a scale ranging from 0 (no perception) to 9 (maximum intensity). Finally, the panellists evaluated the overall pleasantness of the breadsticks using the same scale as the descriptors analysed.

\subsection{Statistical Analysis}

A one-way analysis of variance (ANOVA) followed by the Tukey's HSD test were carried out using the Minitab Statistical Software (Minitab Inc., State College, PA, USA).

\section{Results and Discussion}

\subsection{Proximate Composition of OCP and GF Breadsticks}

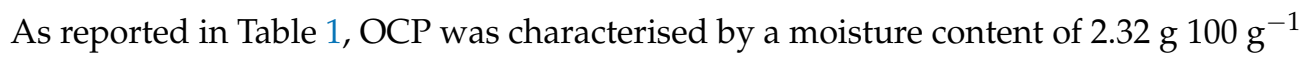
and a high lipid content (mainly monounsaturated), as found by Lozano-Sánchez et al. [36].

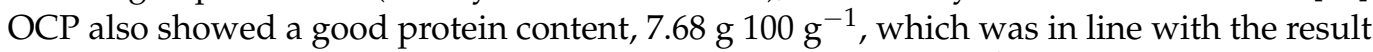

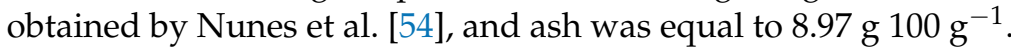


Table 1. Mean values and standard deviation of the proximate composition and bioactive profile of olive cake powder.

\begin{tabular}{|c|c|}
\hline Parameters & OCP \\
\hline Moisture (g $\left.100 \mathrm{~g}^{-1}\right)$ & $2.32 \pm 0.04$ \\
\hline Lipids (g $100 \mathrm{~g}^{-1}$ ) & $22.78 \pm 0.56$ \\
\hline Total dietary fibre $\left(\mathrm{g} 100 \mathrm{~g}^{-1}\right)$ & $23.45 \pm 0.18$ \\
\hline Proteins $\left(\mathrm{g} 100 \mathrm{~g}^{-1}\right)$ & $7.68 \pm 0.12$ \\
\hline Ash $\left(g\right.$ g $\left.100 \mathrm{~g}^{-1}\right)$ & $8.97 \pm 0.34$ \\
\hline Carbohydrates $\left({\left.\mathrm{g} 100 \mathrm{~g}^{-1}\right)}\right.$ & $34.80 \pm 0.25$ \\
\hline \multicolumn{2}{|l|}{ Bioactive compounds } \\
\hline Total phenols (mg GAE g ${ }^{-1}$ ) & $78.23 \pm 0.54$ \\
\hline $\mathrm{DPPH}\left(\mu \mathrm{mol} \mathrm{TE} \mathrm{g}^{-1}\right)$ & $285.24 \pm 11.21$ \\
\hline ABTS $\left(\mu \mathrm{mol} \mathrm{TE} \mathrm{g}^{-1}\right)$ & $346.12 \pm 8.11$ \\
\hline Total tocopherols $\left(\mathrm{mg} \mathrm{kg}^{-1}\right)$ & $412.24 \pm 0.12$ \\
\hline
\end{tabular}

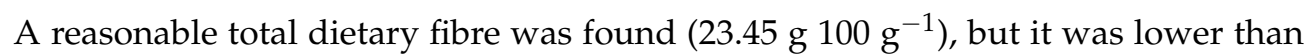
in other studies [55,56]. Moreover, OCP was also a good source of bioactive compounds [57], with values of total phenols and tocopherols equal to $78.23 \mathrm{mg} \mathrm{GAE} \mathrm{g}^{-1}$ and $412.24 \mathrm{mg} \mathrm{kg}^{-1}$, respectively, which contribute to the high antioxidant activity encountered with DPPH and

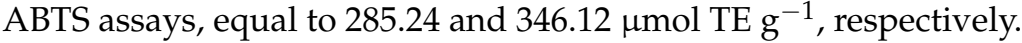

Regarding the GF breadsticks, the addition of OCP positively influenced their quality (Table 2). In particular, the highest content of total dietary fibre was found in BS3 (tz),

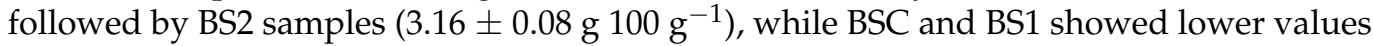
without significant differences. Therefore, both BS2 and BS3 can be labelled as a "source of fibre" in accordance with the EC Regulation n.1924/2006 [58], which states that a food may be labelled as a source of fibre if it contains at least $3 \mathrm{~g}$ of fibre per $100 \mathrm{~g}$ or $1.5 \mathrm{~g}$ per $1000 \mathrm{kcal}$. The higher moisture content observed in the fortified samples could be related to the higher content of fibre known to have water holding and binding capacities [59]; indeed, the same trend was observed by other authors after the addition of fibrous ingredients [60-62]. Even for ash content, BS3 showed a statistically higher content $(2.67 \pm 0.04)$ than for other samples; this result could be reasonably associated with OCP addition, considering the mineral richness of olive cake [63]. Finally, protein and carbohydrate content significantly decreased in the fortified samples (BS1, BS2 and BS3) in comparison with BSC, due to the increase in the other parameters considered.

Table 2. Mean values, standard deviation, and results of statistical analysis of the proximate composition of GF breadsticks.

\begin{tabular}{|c|c|c|c|c|}
\hline Parameters & BSC & BS1 & BS2 & BS3 \\
\hline Moisture (g $\left.100 \mathrm{~g}^{-1}\right)$ & $2.90 \pm 0.02 c$ & $5.02 \pm 0.08 \mathrm{a}$ & $4.18 \pm 0.01 b$ & $4.98 \pm 0.11 \mathrm{a}$ \\
\hline Lipids (g $100 \mathrm{~g}^{-1}$ ) & $14.38 \pm 0.03 b$ & $14.78 \pm 0.23 b$ & $16.14 \pm 0.16 \mathrm{a}$ & $16.08 \pm 0.17 a$ \\
\hline Total dietary fibre $\left({\left.\mathrm{g} 100 \mathrm{~g}^{-1}\right)}^{-1}\right.$ & $2.72 \pm 0.03 c$ & $2.90 \pm 0.08 c$ & $3.16 \pm 0.08 b$ & $3.59 \pm 0.13 a$ \\
\hline Proteins $\left(\mathrm{g} 100 \mathrm{~g}^{-1}\right)$ & $6.23 \pm 0.20 \mathrm{a}$ & $5.58 \pm 0.01 b$ & $5.69 \pm 0.11 b$ & $5.57 \pm 0.02 b$ \\
\hline Ash $\left(g 100 g^{-1}\right)$ & $1.83 \pm 0.03 c$ & $2.43 \pm 0.04 b$ & $2.49 \pm 0.02 b$ & $2.67 \pm 0.04 \mathrm{a}$ \\
\hline Carbohydrates $\left({\left.\mathrm{g} 100 \mathrm{~g}^{-1}\right)}\right.$ & $71.94 \pm 0.20 \mathrm{a}$ & $69.29 \pm 0.21 b$ & $68.34 \pm 0.25 c$ & $67.11 \pm 0.33 d$ \\
\hline
\end{tabular}

Different letters in the same row show significantly different means of data $(p<0.05)$ according to one-way ANOVA and the Tukey's HSD test. Abbreviations: BSC, control breadsticks without olive cake powder; BS1, BS2, BS3, breadsticks with 1,2, and 3\% olive cake powder replacing maize flour, respectively.

\subsection{Phenolic Compounds and Antioxidant Activity of GF Breadsticks}

The maize flour replacement with OCP significantly affected the total phenolic content (TPC) and antioxidant activity (AA) of baked GF breadsticks as reported in Figure 1. A dose-dependent increase in TPC and AA with a higher replacement rate of OCP in the GF breadstick formulation was observed. The significant highest value of TPC was

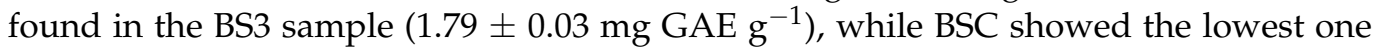


$\left(0.16 \pm 0.01 \mathrm{mg} \mathrm{GAE} \mathrm{g}^{-1}\right)$, and the same trend was found for antioxidant activity. The DPPH values were found in a range of $4.52 \pm 0.19 \mu \mathrm{mol} \mathrm{TE} \mathrm{g}^{-1}$ and $0.88 \pm 0.02 \mu \mathrm{mol}$ $\mathrm{TE}^{-1}$ in BS3 and BSC, respectively. Similarly, also for ABTS, the highest value was found in the BS3 sample, which decreased progressively in the other formulations, reaching the lowest value in the control sample $\left(0.60 \pm 0.01 \mu \mathrm{mol} \mathrm{TE} \mathrm{g}^{-1}\right)$. Therefore, considering the high phenol content in OCP $\left(75.56 \pm 3.34 \mathrm{mg} \mathrm{GAE}^{-1}\right)$, the data obtained highlight a positive correlation between OCP addition and the increase in total phenol content and antioxidant activity found in fortified GF breadsticks. Likewise, the addition of olive cake in fish burgers, pasta, and bread also resulted in an increase in phenol content and antioxidant activities $[48,56,64]$. In addition to olive cake, the addition of other by-products such as apple pomace or grape pomace, as reported by Mir et al. [65] and Rainero et al. [66], respectively, into brown rice flour crackers and wheat breadsticks also enhanced their bioactive content. Pomegranate seed powder has also proven to be an excellent source of phenolic compounds; thus, the addition of increasing amounts (5-10\%) into gluten-free bread entailed a higher total phenol content and antioxidant activity of fortified bread than the control. Similarly, blackcurrant residue added into gluten-free chocolate cookies revealed an interesting potential for enhancing their bioactive content, and furthermore, the authors determined that a large amount of compounds with antioxidant activity could reach the large intestine intact, exerting their antioxidant function until excretion [60].

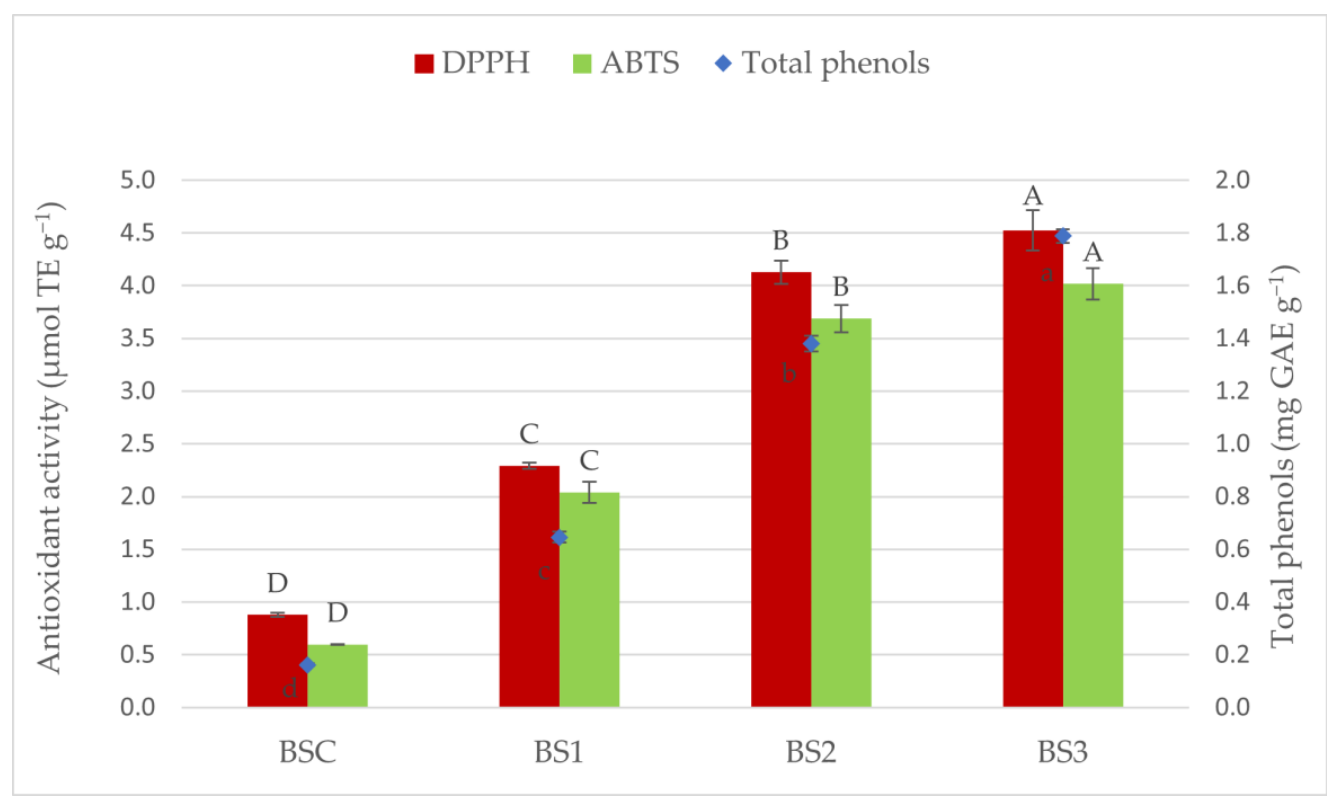

Figure 1. Antioxidant activity and total phenols determination in breadsticks. Different letters show significantly different means of data $(p<0.05)$ according to one-way ANOVA and the Tukey's HSD test. Capital letters refers to antioxidant activity and lowercase letter to total phenols content. Abbreviations: BSC, control breadsticks without OCP; BS1, BS2, BS3, breadsticks with 1, 2, and 3\% olive cake powder replacing maize flour, respectively.

\subsection{Colorimetric and Textural Properties of GF Breadsticks}

The colour and textural properties are fundamental properties for foods' acceptability, particularly for GF products such as bread, pasta, and snacks. These products are usually characterised by a crumbling structure and pale colours [23]. The colour of GF breadsticks was significantly influenced by the addition of OCP (Table 3). Specifically, $L^{*}$ and $b^{*}$ decreased significantly with increasing OCP addition. The browning of GF breadsticks is strictly related to the colour of OCP (brown) added in the formulations. Similar results were obtained by Jahanbakhshi et al. [67] with the addition of olive stone powder into sponge cake, which caused a reduction in $L^{*}$ and $b^{*}$ parameters. Likewise, the colour parameters of gluten-free snacks based on brown rice and amaranth flour added with cactus pear 
peel powder produced by Miranda et al. [68] were also influenced by the addition of the by-product. Specifically, a reduction in luminosity $\left(L^{*}\right)$, but an increase of parameter $a^{*}$, were observed, indicating a shift towards red shades with an increasing amount of cactus pear powder addition. These results emphasise how the raw material colour plays a key role in influencing the colour of finished products. Finally, the total colour difference $(\Delta \mathrm{E})$ highlighted the colour difference between the fortified (BS1, BS2, BS3) and control samples (rice and maize flour), indicating a growing difference with an increasing percentage of olive cake added. In addition to OCP addition, Maillard reactions, which occur in hightemperature-treated products, contribute to the colour, flavour, aroma, and texture of the end product [69].

Table 3. Mean values, standard deviation, and results of statistical analysis of the colorimetric and textural properties of GF breadsticks.

\begin{tabular}{lcccc}
\hline Parameters & BSC & BS1 & BS2 & BS3 \\
\hline Colorimetric & & & & \\
indexes & & & & \\
$L^{*}$ & $61.60 \pm 0.13 \mathrm{a}$ & $53.31 \pm 0.38 \mathrm{~b}$ & $47.18 \pm 0.24 \mathrm{c}$ & $46.07 \pm 0.20 \mathrm{~d}$ \\
$b^{*}$ & $31.89 \pm 0.10 \mathrm{a}$ & $27.22 \pm 0.23 \mathrm{~b}$ & $27.33 \pm 0.54 \mathrm{~b}$ & $26.05 \pm 0.31 \mathrm{c}$ \\
$a^{*}$ & $7.83 \pm 0.10 \mathrm{~b}$ & $7.15 \pm 0.17 \mathrm{c}$ & $8.49 \pm 0.22 \mathrm{a}$ & $7.99 \pm 0.02 \mathrm{~b}$ \\
$\Delta \mathrm{E}$ & - & $9.55 \pm 0.53 \mathrm{a}$ & $15.15 \pm 0.19 \mathrm{~b}$ & $16.60 \pm 0.22 \mathrm{c}$ \\
Textural indexes & & & & \\
Hardness (N) & $19.12 \pm 0.72 \mathrm{a}$ & $19.40 \pm 0.32 \mathrm{a}$ & $18.91 \pm 0.75 \mathrm{a}$ & $12.68 \pm 0.16 \mathrm{~b}$ \\
Brittleness (mm) & $0.08 \pm 0.02 \mathrm{a}$ & $0.09 \pm 0.01 \mathrm{a}$ & $0.10 \pm 0.02 \mathrm{a}$ & $0.07 \pm 0.01 \mathrm{a}$ \\
\hline
\end{tabular}

Different letters in the same row show significantly different means of data $(p<0.05)$ according to one-way ANOVA and the Tukey's HSD test. Abbreviations: BSC, control breadsticks without olive cake powder; BS1, BS2, BS3, breadsticks with 1, 2, and 3\% olive cake powder replacing maize flour, respectively.

Maillard reactions take place between amine groups, in amino acids and proteins, and carbonyl compounds, which usually come from the reducing of sugars (fructose, glucose, maltose, or lactose) [70]. The colour development is ascribed to the final stage of the Maillard reaction, where the condensation of carbonyls and amines provokes the formation of brown-coloured, high-molecular-weight compounds, named melanoidins [71,72].

Hardness and brittleness are common parameters considered for the evaluation of the textural properties of baked snacks, being closely related with their freshness and wholesomeness [73]. As reported in Table 3, BS3 showed the lowest value of hardness $(12.68 \mathrm{~N})$ when compared with BS2, BS1, and BSC that all showed no significant differences. Among the factors which can affect the textural parameters of bakery foods, lipids exert a fundamental role, acting as a lubricant. However, their impact on GF bakery foods is less relevant for the absence of interactions with the gluten network [74].

According to the literature, flour particle size may have affected the structure of the final product; specifically, the addition of coarse flours led to a hardness reduction of several bakery products [75-78]. From the results obtained by Mancebo et al. [78], it was observed that gluten-free cookies prepared with coarse-grained flour required a significant lower peak force than cookies prepared with fine-grained flours. A similar result was obtained by Belorio et al. [76], who assessed that hardness was most affected by particle size, followed by diameter and spread factor. Specifically, the authors observed a reduction in hardness with an increasing percentage of coarse maize flour inclusion in the preparation of gluten-free cookies. Therefore, the addition of a large amount of coarse and uneven OCP could have determined the formation of a more fragile structure, which positively affected hardness by reducing it. Moreover, the textural properties of final products may be affected by the nature of the fibres (soluble or insoluble), as well as size, morphology, and technological properties such as water binding and holding capacity, which can affect the water content of the end product $[62,79,80]$. According to Šarić et al. [81], the positive correlation existing between a high amount of water in the system and the lower breaking force (hardness) of gluten-free cookies with added blueberry pomace derives from the penetration of water in the starch granules, which swelled. This phenomenon determined an increase in intramolecular bond 
breakage and macromolecule mobility, with a consequently less-dense cookie structure and lower breaking force. On the contrary, a reduction in volume and firmer crumbs occurred in gluten-free bread to which quinoa bran was added [82]. According to the authors, a possible explanation is the competition of dietary fibre and starch for water absorption and the resulting limited starch swelling and gelatinisation. Similarly, Raczyk et al. [83] observed an increase in bread hardness after 48 and $72 \mathrm{~h}$ of storage with coconut and chestnut flour supplementation, because of fibre and sugar increases. Regarding brittleness, it refers to the distance crossed by the tool before the breadsticks breaks. For this parameter, no significant differences were found among the samples, although BS3 displayed a slightly higher brittleness as a consequence of its lower hardness value [84].

\subsection{Volatile Profile of GF Breadsticks}

For baked foods such as biscuits, crackers, and breadsticks, lipid oxidation represents one of the main causes of quality deterioration [85], and pentanal, hexanal, trans2-heptanal, and nonanal are aldehydes considered to be markers of lipid oxidation [86-88]. Table 4 reports the volatile compounds of GF breadsticks and a total of 44 volatile compounds were identified: 12 aldehydes, 13 pyrazines, 8 ketones and esters, 9 furans, and 2 acids.

Table 4. Mean values, standard deviation, and results of statistical analysis of the volatile compounds (expressed as $\mu \mathrm{g} \mathrm{g}^{-1}$ ) into GF breadsticks.

\begin{tabular}{|c|c|c|c|c|}
\hline Volatile Compounds & BSC & BS1 & BS2 & BS3 \\
\hline \multicolumn{5}{|l|}{ Aldehydes } \\
\hline 2-Methylpropanal & $13.04 \pm 0.43 a$ & $4.89 \pm 0.63 c$ & $6.85 \pm 0.29 b$ & $5.35 \pm 0.25 c$ \\
\hline 2-Methylbutanal & $29.34 \pm 1.26 a$ & $10.80 \pm 0.72 c$ & $13.21 \pm 0.54 b$ & $10.13 \pm 0.20 c$ \\
\hline 3-Methylbutyraldehyde & $95.50 \pm 5.53 a$ & $35.33 \pm 1.39 b$ & $38.24 \pm 0.38 b$ & $22.95 \pm 1.62 c$ \\
\hline Pentanal & $3.74 \pm 0.55 a$ & $2.10 \pm 0.11 b$ & $2.33 \pm 0.17 \mathrm{~b}$ & $1.96 \pm 0.05 b$ \\
\hline 2-Butenal & $1.05 \pm 0.30 \mathrm{a}$ & $0.36 \pm 0.13 b$ & $0.58 \pm 0.08 b$ & $0.42 \pm 0.11 b$ \\
\hline Hexanal & $24.66 \pm 2.83 a$ & $12.48 \pm 0.69 b$ & $12.54 \pm 0.67 \mathrm{~b}$ & $14.19 \pm 0.91 b$ \\
\hline Heptanal & $3.60 \pm 0.19 a$ & $1.24 \pm 0.21 \mathrm{c}$ & $2.85 \pm 0.17 \mathrm{ab}$ & $1.99 \pm 0.70 b c$ \\
\hline Octanal & $1.56 \pm 0.46 a$ & $0.82 \pm 0.19 b$ & $1.77 \pm 0.13 a$ & $1.53 \pm 0.09 a$ \\
\hline trans-2-heptenal & $10.97 \pm 0.12 a$ & $9.21 \pm 0.18 b$ & $9.04 \pm 0.77 \mathrm{~b}$ & $7.52 \pm 0.38 c$ \\
\hline Nonanal & $0.98 \pm 0.12 \mathrm{a}$ & $0.72 \pm 0.07 \mathrm{a}$ & $0.83 \pm 0.20 \mathrm{a}$ & $0.85 \pm 0.20 \mathrm{a}$ \\
\hline trans-2-octenal & $0.74 \pm 0.10 \mathrm{a}$ & $0.58 \pm 0.23 a$ & $0.65 \pm 0.07 a$ & $0.74 \pm 0.17 \mathrm{a}$ \\
\hline Benzaldehyde & $5.83 \pm 0.66 \mathrm{~d}$ & $29.40 \pm 1.38 c$ & $75.94 \pm 4.10 \mathrm{~b}$ & $112.30 \pm 11.48 \mathrm{a}$ \\
\hline \multicolumn{5}{|l|}{ Ketones and esters } \\
\hline 2-Butanone & $10.08 \pm 0.92 \mathrm{a}$ & $1.49 \pm 0.0 .8 b$ & $2.28 \pm 0.25 b$ & $1.97 \pm 0.05 b$ \\
\hline 2-Pentanone & $0.62 \pm 0.03 a$ & $0.17 \pm 0.09 b$ & $0.15 \pm 0.03 b$ & $0.14 \pm 0.02 b$ \\
\hline 2,3-Butanedione & $15.30 \pm 0.86 a$ & $7.12 \pm 0.38 c$ & $7.39 \pm 0.29 c$ & $11.00 \pm 0.39 b$ \\
\hline 2,3-Pentanedione & $12.95 \pm 0.83 a$ & $5.24 \pm 0.62 c$ & $7.49 \pm 0.49 b$ & $8.18 \pm 0.58 b$ \\
\hline 2-Heptanone & $6.76 \pm 0.90 \mathrm{a}$ & $0.54 \pm 0.07 \mathrm{c}$ & $1.99 \pm 0.22 b$ & $1.22 \pm 0.26 b c$ \\
\hline 2-Octanone & $0.35 \pm 0.02 \mathrm{a}$ & $0.15 \pm 0.03 b$ & $0.17 \pm 0.03 b$ & $0.10 \pm 0.02 b$ \\
\hline 1-Octen-3-one & $0.79 \pm 0.30 \mathrm{bc}$ & $0.77 \pm 0.14 \mathrm{c}$ & $1.24 \pm 0.06 \mathrm{ab}$ & $1.29 \pm 0.10 \mathrm{a}$ \\
\hline Ethanone, 1-(2-furanyl) & $1.01 \pm 0.15 a$ & $0.44 \pm 0.06 b$ & $0.47 \pm 0.05 b$ & $0.58 \pm 0.03 b$ \\
\hline \multicolumn{5}{|l|}{ Acids } \\
\hline Propanoic acid & $1.11 \pm 0.06 \mathrm{a}$ & $1.15 \pm 0.10 b$ & $1.68 \pm 0.07 \mathrm{~b}$ & $1.05 \pm 0.06 \mathrm{~b}$ \\
\hline Acetic acid & $0.30 \pm 0.16 b$ & $0.14 \pm 0.04 b$ & $0.26 \pm 0.03 b$ & $0.83 \pm 0.12 \mathrm{a}$ \\
\hline \multicolumn{5}{|l|}{ Furans } \\
\hline Furan & $4.25 \pm 0.85 a$ & $1.07 \pm 0.33 b$ & $2.22 \pm 0.16 b$ & $2.25 \pm 0.12 b$ \\
\hline Furan, 2-methyl- & $18.69 \pm 1.17 a$ & $2.44 \pm 0.25 c$ & $1.99 \pm 0.20 c$ & $19.01 \pm 0.64 b$ \\
\hline Furan, 2-ethyl- & $1.56 \pm 0.13 a$ & $0.16 \pm 0.04 \mathrm{c}$ & $0.41 \pm 0.07 \mathrm{~b}$ & $0.56 \pm 0.05 b$ \\
\hline Furan, 2-pentyl- & $1.55 \pm 0.17 \mathrm{a}$ & $0.73 \pm 0.03 b$ & $1.41 \pm 0.09 a$ & $0.74 \pm 0.04 b$ \\
\hline 2(3H)-Furanone, 5-methyl & $0.46 \pm 0.03 a$ & $0.16 \pm 0.05 b$ & $0.13 \pm 0.03 b$ & $0.19 \pm 0.02 b$ \\
\hline 2-Furancarboxaldehyde & $11.36 \pm 0.79 \mathrm{a}$ & $4.63 \pm 0.51 c$ & $5.21 \pm 0.57 c$ & $6.89 \pm 0.48 b$ \\
\hline 2-Furancarboxaldehyde,5-methyl & $0.69 \pm 0.07 \mathrm{~b}$ & $0.73 \pm 0.08 b$ & $1.05 \pm 0.18 \mathrm{a}$ & $0.40 \pm 0.04 \mathrm{c}$ \\
\hline 2(3H)-Furanone, dihydro- & $1.27 \pm 0.14 \mathrm{a}$ & $0.73 \pm 0.04 b$ & $0.62 \pm 0.04 b$ & $0.89 \pm 0.18 b$ \\
\hline 2-Furanmethanol & $40.50 \pm 0.79 a$ & $10.49 \pm 0.54 b c$ & $9.21 \pm 0.55 c$ & $11.84 \pm 0.77 \mathrm{~b}$ \\
\hline Sulfurs & & & & \\
\hline
\end{tabular}


Table 4. Cont.

\begin{tabular}{lcccc}
\hline Volatile Compounds & BSC & BS1 & BS2 & BS3 \\
\hline Carbon disulfide & $1.41 \pm 0.17 \mathrm{a}$ & $1.03 \pm 0.05 \mathrm{a}$ & $1.29 \pm 0.13 \mathrm{a}$ & $1.44 \pm 0.36 \mathrm{a}$ \\
Pirazines & $7.82 \pm 0.27 \mathrm{a}$ & $1.97 \pm 0.54 \mathrm{~b}$ & $1.33 \pm 0.08 \mathrm{~b}$ & $1.75 \pm 0.46 \mathrm{~b}$ \\
Pyrazine & $31.46 \pm 0.86 \mathrm{a}$ & $12.26 \pm 1.35 \mathrm{~b}$ & $12.32 \pm 0.52 \mathrm{~b}$ & $6.92 \pm 1.87 \mathrm{c}$ \\
Pyrazine, methyl- & $6.02 \pm 0.30 \mathrm{a}$ & $3.23 \pm 0.13 \mathrm{~b}$ & $3.45 \pm 0.14 \mathrm{~b}$ & $2.48 \pm 0.26 \mathrm{c}$ \\
Pyrazine, 2,6-dimethyl- & $14.09 \pm 0.62 \mathrm{a}$ & $6.41 \pm 0.56 \mathrm{~b}$ & $5.46 \pm 0.21 \mathrm{~b}$ & $3.25 \pm 0.04 \mathrm{c}$ \\
Pyrazine, ethyl- & $5.56 \pm 0.42 \mathrm{a}$ & $2.58 \pm 0.47 \mathrm{~b}$ & $1.71 \pm 0.13 \mathrm{c}$ & $0.77 \pm 0.03 \mathrm{~d}$ \\
Pyrazine, 2,3-dimethyl- & $3.53 \pm 0.18 \mathrm{a}$ & $1.44 \pm 0.20 \mathrm{~b}$ & $1.78 \pm 0.44 \mathrm{~b}$ & $1.81 \pm 0.12 \mathrm{~b}$ \\
Pyrazine, 2-ethyl-6-methyl- & $7.28 \pm 0.26 \mathrm{a}$ & $4.95 \pm 0.78 \mathrm{~b}$ & $4.83 \pm 0.48 \mathrm{~b}$ & $4.92 \pm 0.36 \mathrm{~b}$ \\
Pyrazine, 2-ethyl-5-methyl- & $4.66 \pm 0.26 \mathrm{a}$ & $2.29 \pm 0.03 \mathrm{~b}$ & $1.80 \pm 0.06 \mathrm{c}$ & $1.11 \pm 0.04 \mathrm{~d}$ \\
Pyrazine, 2-ethyl-3-methyl- & $0.74 \pm 0.08 \mathrm{a}$ & $0.25 \pm 0.02 \mathrm{~b}$ & $0.22 \pm 0.03 \mathrm{~b}$ & $0.23 \pm 0.04 \mathrm{~b}$ \\
Pyrazine, propyl- & $0.74 \pm 0.10 \mathrm{a}$ & $0.58 \pm 0.23 \mathrm{~b}$ & $0.65 \pm 0.07 \mathrm{~b}$ & $0.74 \pm 0.17 \mathrm{~b}$ \\
Pyrazine, ethenyl & $1.10 \pm 0.09 \mathrm{a}$ & $0.45 \pm 0.08 \mathrm{~b}$ & $0.47 \pm 0.06 \mathrm{~b}$ & $0.34 \pm 0.03 \mathrm{~b}$ \\
Pyrazine, 3-ethyl-2,5-dimethyl- & $0.77 \pm 0.08 \mathrm{ab}$ & $0.37 \pm 0.03 \mathrm{a}$ & $0.34 \pm 0.04 \mathrm{ab}$ & $0.27 \pm 0.05 \mathrm{~b}$ \\
Pyrazine, 2-ethyl-3,5-dimethyl- & $0.84 \pm 0.08 \mathrm{a}$ & $0.62 \pm 0,05 \mathrm{a}$ & $0.74 \pm 0.10 \mathrm{a}$ & $0.84 \pm 0.12 \mathrm{a}$ \\
Pyrazine, 2-ethenyl-6-methyl & & & \\
\hline
\end{tabular}

Different letters in the same row show significantly different means of data $(p<0.05)$ according to one-way ANOVA and the Tukey's HSD test. Abbreviations: BSC, control breadsticks without olive cake powder; BS1, BS2, BS3, breadsticks with 1, 2, and 3\% olive cake powder replacing maize flour, respectively.

From the data reported, a general reduction in the concentration of the aforementioned aldehydes in GF breadsticks added with OCP (BS1, BS2, and BS3) could be observed when compared to BSC (control sample without OCP). This could be related to the higher antioxidant activity and phenolic compounds (Figure 1) able to inactivate free radicals, stabilising them through their transfer of a hydrogen atom or a single electron [89]. Therefore, a delay in the oxidation process of the products can be assumed, as was also observed by Difonzo et al. [53] by adding olive leaf extract (OLE) in baked snacks. Even Rutkowska et al. [90] found a reduction in the hydroperoxide content in muffins fortified with increasing concentrations of chokeberry polyphenol extract (ChPE) $(0.25,0.50$, and $0.70 \%$ ) after eight weeks of storage. However, Rutkowska et al. [90] highlighted that there was no direct correlation between the amount of ChPE added and lipid oxidation inhibition. Furthermore, Maillard reactions, as already mentioned, contribute in a significant way to the aroma and flavour of baked foods through the production of a wide range of volatile compounds [69].

Strecker aldehydes, furans, pyrazines, and ketones are the main classes of volatile compounds that develop during Maillard reactions, which contribute to conferring the typical aroma to bakery products such as bread, cookies, and cakes [91,92]. Strecker degradation is one of the main stages of Maillard reactions, which occurs between $\alpha$-di-carbonyl compounds produced by carbohydrate dehydration, or fragmentation, and amino acids, and leads to the production of aldehydes with the corresponding structure of the initial amino acids [92,93]. Notably, 3-methylbutyraldehydes, 2-methylbutanal, and 2-methylpropanal, derive, respectively, from leucine, isoleucine, and valine [94,95], and their concentration was reduced by 75, 65.5, and $59 \%$ in BS3 when compared with the control sample, BSC.

An opposite trend was found for benzaldehyde, whose concentration increased proportionally to OCP addition, reaching a value of $112.30 \mu \mathrm{g} \mathrm{g}^{-1}$ in BS3 when compared to BSC $\left(5.83 \mu \mathrm{g} \mathrm{g}^{-1}\right)$. Benzaldehyde is another characteristic compound of Maillard reactions [72,96], but from a literature analysis it emerged that this compound is also characteristic of drupaceous fruits; therefore olives and its derived products would justify the increase in its concentration with increasing quantities of OCP added in the GF breadstick formulation [97-100].

Furthermore, furans and pyrazines followed the same trend of Strecker aldehydes, with, generally, a significant decrease in their concentration in enriched GF breadsticks. Among furans, 2-furanmethanol was the most abundant, which gives aromas of toasted caramel and nuts [87]. Pyrazines are usually formed by interaction between the products of Maillard reactions and Strecker degradation and, together with furans, significantly 
contribute to the flavour of baked products $[87,96]$. Nevertheless, several studies highlighted the influence of phenolic compounds on the development of volatile compounds in the end products $[93,101-104]$. The inhibitory action of polyphenols against aromatic compounds can be regulated by three mechanisms: entrapment of di-carbonyl groups from sugar fragmentation, reaction of their degradation products with aromatic compounds, or they can act as radical scavengers of free radicals involved in Maillard reactions, inhibiting flavour formation [105]. According to Hidalgo et al. [106], the ability of phenols to trap Strecker aldehydes is related to the high nucleophilicity of their atoms. However, their trapping ability is not the same in all aldehydes and the formation of carbonyl-phenol is connected with the structure of both the phenols and aldehydes involved [106].

Moreover, Mildner-Szkudlarz et al. [102,107] assessed the inhibitory action of phenolic compounds (mainly gallic and caffeic acids, followed by ferulic acid, catechins, and quercetin) against pyrazine and furan production during bread baking, confirming our results. Similarly, a significant reduction in furans, Strecker aldehydes, and pyrazines occurred in a coffee-canned model system through the addition of di-carbonyl trapping agent, water, and fat-soluble antioxidants and reducing agents (glutathione and sodium sulphite) [103].

\subsection{Sensory Profile}

In general, the addition of OCP significantly influenced sensory parameters. The results (Table 5) showed a significant increase in colour intensity proportionally to OCP added in GF breadstick formulation, with the highest values in BS2 (7.50 \pm 0.55$)$ and BS3 $(6.57 \pm 1.25)$. The result was in line with colorimetric analysis, where a reduction in luminosity $\left(L^{*}\right)$ and yellow index $\left(b^{*}\right)$ was observed. The same results were found by Cecchi et al. [108] after the addition of olive cake for granola bar manufacturing. No differences were observed for surface and colour uniformity between enriched samples and control, with the exception of sample BS1, due to the manual manufacturing. Regarding flavour, panellists perceived a higher olive hint in BS2 and BS3 than in BS1. Furthermore, BS3 was perceived as less hard and more brittle, confirming the instrumental results on texture profile. With respect to taste, panellists perceived a higher intensity of bitterness and astringency in the BS3 sample, which may be reasonably associated with the highest phenol concentration known to provide bitter and astringent sensations [109-111]. Moreover, oiliness perception was greater in the BS2 and BS3 samples, but no differences were perceived among the samples for saltiness. According to the overall pleasantness results, OCP improved the acceptability of GF breadsticks; indeed, BS2 and BS3 received an overall pleasing score, higher than for BS1 and BSC.

Table 5. Mean values, standard deviation, and results of statistical analysis of the sensorial analysis of GF breadsticks.

\begin{tabular}{lcccc}
\hline Parameters & BSC & BS1 & BS2 & BS3 \\
\hline Appearance & & & & \\
Colour uniformity & $7.83 \pm 0.82 \mathrm{a}$ & $5.67 \pm 0.82 \mathrm{~b}$ & $7.08 \pm 0.67 \mathrm{a}$ & $8.25 \pm 0.61 \mathrm{a}$ \\
Colour intensity & $1.92 \pm 0.20 \mathrm{c}$ & $4.92 \pm 0.20 \mathrm{~b}$ & $7.50 \pm 0.55 \mathrm{a}$ & $7.92 \pm 0.80 \mathrm{a}$ \\
Surface uniformity & $7.17 \pm 0.98 \mathrm{ab}$ & $5.83 \pm 0.98 \mathrm{~b}$ & $7.67 \pm 0.82 \mathrm{a}$ & $6.67 \pm 1.37 \mathrm{ab}$ \\
Flavour & & & \\
Olive & - & $1.67 \pm 1.21 \mathrm{~b}$ & $5.33 \pm 1.03 \mathrm{a}$ & $6.42 \pm 0.92 \mathrm{a}$ \\
Texture & & & \\
Hardness & $6.42 \pm 1.20 \mathrm{a}$ & $5.50 \pm 1.38 \mathrm{a}$ & $5.50 \pm 1.23 \mathrm{a}$ & $3.58 \pm 0.80 \mathrm{~b}$ \\
Brittleness & $4.00 \pm 0.63 \mathrm{~b}$ & $4.17 \pm 0.98 \mathrm{~b}$ & $6.50 \pm 0.55 \mathrm{a}$ & $7.00 \pm 0.84 \mathrm{a}$ \\
Taste & & & \\
Salty & $1.91 \pm 0.92 \mathrm{a}$ & $2.42 \pm 0.67 \mathrm{a}$ & $2.33 \pm 0.52 \mathrm{a}$ & $2.50 \pm 0.55 \mathrm{a}$ \\
Bitterness & $0.58 \pm 0.49 \mathrm{c}$ & $2.25 \pm 0.88 \mathrm{~b}$ & $3.42 \pm 1.02 \mathrm{~b}$ & $5.50 \pm 1.05 \mathrm{a}$ \\
Astringency & $0.33 \pm 0.52 \mathrm{~b}$ & $1.00 \pm 1.27 \mathrm{~b}$ & $0.83 \pm 0.98 \mathrm{~b}$ & $3.67 \pm 1.97 \mathrm{a}$ \\
Oiliness & $1.08 \pm 1.02 \mathrm{~b}$ & $0.92 \pm 0.67 \mathrm{~b}$ & $1.42 \pm 1.11 \mathrm{ab}$ & $2.67 \pm 1.03 \mathrm{a}$ \\
Overall pleasantness & $5.42 \pm 0.92 \mathrm{~b}$ & $5.92 \pm 0.49 \mathrm{~b}$ & $7.67 \pm 0.75 \mathrm{a}$ & $7.92 \pm 0.19 \mathrm{a}$ \\
\hline Different letters in the same row show significantly different means of data $(p<0.05)$ according to one-way
\end{tabular}

Different letters in the same row show significantly different means of data $(p<0.05)$ according to one-way ANOVA and the Tukey's HSD test. Abbreviations: BSC, control breadsticks without olive cake powder; BS1, BS2, BS3, breadsticks with 1,2, and 3\% olive cake powder replacing maize flour, respectively. 


\section{Conclusions}

The obtained results demonstrated how OCP addition into GF breadstick formulations was able to enhance the overall quality of the end products through the exploitation of a byproduct in a sustainable perspective. The replacement of maize flour with OCP determined an increase in lipids, ash, moisture, and total dietary fibre in the enriched samples. BS2 and

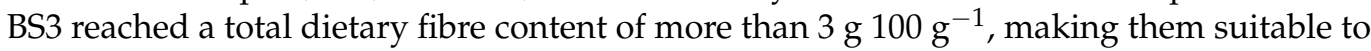
be labelled as a "source of fibre". The addition of OCP allowed us to improve total phenol content and antioxidant activity, which are supposed to reduce the concentration of some aldehydes, markers of lipids oxidation, and the main volatile classes of Maillard reactions in fortified breadsticks. Finally, OCP addition induced a reduction in hardness and an improvement in overall pleasantness, as evaluated by the sensory evaluation.

Author Contributions: Conceptualization, G.D. and F.C.; methodology and formal analysis, G.d.G. and G.D.; writing-original draft preparation, G.d.G., G.D. and F.C.; writing-review and editing, G.d.G., G.D., C.S., A.P. and F.C. All authors have read and agreed to the published version of the manuscript.

Funding: This research received no external funding.

Data Availability Statement: The data presented in this study are available on request from the corresponding author.

Acknowledgments: This work was supported by POR Puglia 2014/2020-Asse X-Azione 10.4 Research for Innovation- REFIN code n. E65BAEEE.

Conflicts of Interest: The authors declare no conflict of interest.

\section{References}

1. Runde, J.; Mears, M.; Guandalini, S.; Jericho, H. A Narrow Window: Booming Gluten-free Market and Fostering Healthy Dietary Habits in Children With Celiac Disease. J. Pediatr. Gastroenterol. Nutr. 2020, 71, 533-535. [CrossRef] [PubMed]

2. Xhakollari, V.; Canavari, M.; Osman, M. Factors affecting consumers' adherence to gluten-free diet, a systematic review. Trends Food Sci. Technol. 2019, 85, 23-33. [CrossRef]

3. Cardo, A.; Churruca, I.; Lasa, A.; Navarro, V.; Vázquez-Polo, M.; Perez-Junkera, G.; Larretxi, I. Nutritional Imbalances in Adult Celiac Patients Following a Gluten-Free Diet. Nutrients 2021, 13, 2877. [CrossRef] [PubMed]

4. Babio Sánchez, N.; Lladó Bellette, N.; Besora-Moreno, M.; Castillejo, G.; Guillén, N.; Martínez-Cerezo, F.; Viíchez, E.; Roger, E.; Salas Salvadó, J. A comparison of the nutritional profile and price of gluten-free products and their gluten-containing counterparts available in the Spanish market. Nutr. Hosp. 2020, 37, 814-822. [CrossRef] [PubMed]

5. Fry, L.; Madden, A.M.; Fallaize, R. An investigation into the nutritional composition and cost of gluten-free versus regular food products in the UK. J. Hum. Nutr. Diet. 2018, 31, 108-120. [CrossRef] [PubMed]

6. Vici, G.; Belli, L.; Biondi, M.; Polzonetti, V. Gluten free diet and nutrient deficiencies: A review. Clin. Nutr. 2016, 35, 1236-1241. [CrossRef] [PubMed]

7. Caponio, F.; Summo, C.; Clodoveo, M.L.; Pasqualone, A. Evaluation of the nutritional quality of the lipid fraction of gluten-free biscuits. Eur. Food Res. Technol. 2008, 227, 135-139. [CrossRef]

8. Lerner, A.; O'Bryan, T.; Matthias, T. Navigating the Gluten-Free Boom: The Dark Side of Gluten Free Diet. Front. Pediatr. 2019, 7, 414. [CrossRef]

9. Phimolsiripol, Y.; Mukprasirt, A.; Schoenlechner, R. Quality improvement of rice-based gluten-free bread using different dietary fibre fractions of rice bran. J. Cereal Sci. 2012, 56, 389-395. [CrossRef]

10. Calvo-Lerma, J.; Crespo-Escobar, P.; Martínez-Barona, S.; Fornés-Ferrer, V.; Donat, E.; Ribes-Koninckx, C. Differences in the macronutrient and dietary fibre profile of gluten-free products as compared to their gluten-containing counterparts. Eur. J. Clin. Nutr. 2019, 73, 930-936. [CrossRef]

11. Matos, M.E.; Rosell, C.M. Understanding gluten-free dough for reaching breads with physical quality and nutritional balance. J. Sci. Food Agric. 2015, 95, 653-661. [CrossRef] [PubMed]

12. Di Cairano, M.; Galgano, F.; Tolve, R.; Caruso, M.C.; Condelli, N. Focus on gluten free biscuits: Ingredients and issues. Trends Food Sci. Technol. 2018, 81, 203-212. [CrossRef]

13. Gallagher, E.; Gormley, T.; Arendt, E. Recent advances in the formulation of gluten-free cereal-based products. Trends Food Sci. Technol. 2004, 15, 143-152. [CrossRef]

14. Fiorda, F.A.; Soares, M.S.; da Silva, F.A.; Grosmann, M.V.E.; Souto, L.R.F. Microestructure, texture and colour of gluten-free pasta made with amaranth flour, cassava starch and cassava bagasse. LWT Food Sci. Technol. 2013, 54, 132-138. [CrossRef]

15. Raungrusmee, S.; Shrestha, S.; Sadiq, M.B.; Anal, A.K. Influence of resistant starch, xanthan gum, inulin and defatted rice bran on the physicochemical, functional and sensory properties of low glycemic gluten-free noodles. LWT 2020, 126, 109279. [CrossRef] 
16. Mariotti, M.; Pagani, M.A.; Lucisano, M. The role of buckwheat and HPMC on the breadmaking properties of some commercial gluten-free bread mixtures. Food Hydrocoll. 2013, 30, 393-400. [CrossRef]

17. Milde, L.B.; Chigal, P.S.; Olivera, J.E.; González, K.G. Incorporation of xanthan gum to gluten-free pasta with cassava starch Physical, textural and sensory attributes. LWT 2020, 131, 109674. [CrossRef]

18. Ziobro, R.; Juszczak, L.; Witczak, M.; Korus, J. Non-gluten proteins as structure forming agents in gluten free bread. J. Food Sci. Technol. 2016, 53, 571-580. [CrossRef]

19. Horstmann, S.W.; Foschia, M.; Arendt, E.K. Correlation analysis of protein quality characteristics with gluten-free bread properties Food Funct. 2017, 8, 2465-2474. [CrossRef] [PubMed]

20. Ungureanu-Iuga, M.; Dimian, M.; Mironeasa, S. Development and quality evaluation of gluten-free pasta with grape peels and whey powders. LWT 2020, 130, 109714. [CrossRef]

21. Aguiar, E.V.; Santos, F.G.; Centeno, A.C.L.S.; Capriles, V.D. Influence of pseudocereals on gluten-free bread quality: A study integrating dough rheology, bread physical properties and acceptability. Food Res. Int. 2021, 150, 110762. [CrossRef] [PubMed]

22. Ziemichód, A.; Wójcik, M.; Różyło, R. Seeds of Plantago psyllium and Plantago ovata: Mineral composition, grinding, and use for gluten-free bread as substitutes for hydrocolloids. J. Food Process Eng. 2019, 42, e12931. [CrossRef]

23. Conte, P. Technological and Nutritional Challenges, and Novelty in Gluten-Free Breadmaking: A Review. Polish J. Food Nutr. Sci. 2019, 69, 5-21. [CrossRef]

24. Hussain, S.; Jõudu, I.; Bhat, R. Dietary Fiber from Underutilized Plant Resources-A Positive Approach for Valorization of Fruit and Vegetable Wastes. Sustainability 2020, 12, 5401. [CrossRef]

25. Ngemakwe, P.N.; Le Roes-Hill, M.; Jideani, V. Advances in gluten-free bread technology. Food Sci. Technol. Int. 2015, 21, 256-276. [CrossRef] [PubMed]

26. Naqash, F.; Gani, A.; Gani, A.; Masoodi, F.A. Gluten-free baking: Combating the challenges-A review. Trends Food Sci. Technol. 2017, 66, 98-107. [CrossRef]

27. Coman, V.; Teleky, B.E.; Mitrea, L.; Martău, G.A.; Szabo, K.; Călinoiu, L.F.; Vodnar, D.C. Bioactive potential of fruit and vegetable wastes. Adv. Food Nutr. Res. 2020, 91, 157-225. [CrossRef]

28. Schieber, A. By-Products of Plant Food Processing as a Source of Valuable Compounds. Ref. Modul. Food Sci. 2019, 12, 401-413. [CrossRef]

29. Difonzo, G.; de Gennaro, G.; Pasqualone, A.; Caponio, F. Potential use of plant-based by-products and waste to improve the quality of gluten-free foods. J. Sci. Food Agric. 2021. [CrossRef]

30. Gullón, P.; Gullón, B.; Astray, G.; Carpena, M.; Fraga-Corral, M.; Prieto, M.A.; Simal-Gandara, J. Valorization of by-products from olive oil industry and added-value applications for innovative functional foods. Food Res. Int. 2020, 137, 109683. [CrossRef]

31. Cedola, A.; Cardinali, A.; D'Antuono, I.; Conte, A.; Del Nobile, M.A. Cereal foods fortified with by-products from the olive oil industry. Food Biosci. 2020, 33, 100490. [CrossRef]

32. Lanza, B.; Cellini, M.; Di Marco, S.; D’Amico, E.; Simone, N.; Giansante, L.; Pompilio, A.; Di Loreto, G.; Bacceli, M.; Del Re, P.; et al. Olive Pâté by Multi-Phase Decanter as Potential Source of Bioactive Compounds of Both Nutraceutical and Anticancer Effects. Molecules 2020, 25, 5967. [CrossRef] [PubMed]

33. Tufariello, M.; Durante, M.; Veneziani, G.; Taticchi, A.; Servili, M.; Bleve, G.; Mita, G. Patè olive cake: Possible exploitation of a by-product for food applications. Front. Nutr. 2019, 6, 3. [CrossRef]

34. Dinu, M.; Pagliai, G.; Scavone, F.; Bellumori, M.; Cecchi, L.; Nediani, C.; Maggini, N.; Sofi, F.; Giovannelli, L.; Mulinacci, N. Effects of an Olive By-Product Called Pâté on Cardiovascular Risk Factors. J. Am. Coll. Nutr. 2021, 40, 617-623. [CrossRef]

35. Cavallo, P.; Dini, I.; Sepe, I.; Galasso, G.; Fedele, F.L.; Sicari, A.; Bolletti Censi, S.; Gaspari, A.; Ritieni, A.; Lorito, M.; et al. An Innovative Olive Pâté with Nutraceutical Properties. Antioxidants 2020, 9, 581. [CrossRef] [PubMed]

36. Lozano-Sánchez, J.; Bendini, A.; Di Lecce, G.; Valli, E.; Gallina Toschi, T.; Segura-Carretero, A. Macro and micro functional components of a spreadable olive by-product (pâté) generated by new concept of two-phase decanter. Eur. J. Lipid Sci. Technol. 2017, 119, 1600096. [CrossRef]

37. López-Marcos, M.C.; Bailina, C.; Viuda-Martos, M.; Pérez-Alvarez, J.A.; Fernández-López, J. Properties of Dietary Fibers from Agroindustrial Coproducts as Source for Fiber-Enriched Foods. Food Bioprocess Technol. 2015, 8, 2400-2408. [CrossRef]

38. Anderson, J.W.; Baird, P.; Davis, R.H.; Ferreri, S.; Knudtson, M.; Koraym, A.; Waters, V.; Williams, C.L. Health benefits of dietary fiber. Nutr. Rev. 2009, 67, 188-205. [CrossRef]

39. Yangilar, F. The Application of Dietary Fibre in Food Industry: Structural Features, Effects on Health and Definition, Obtaining and Analysis of Dietary Fibre: A Review. J. Food Nutr. Res. 2013, 1, 13-23. [CrossRef]

40. Dhingra, D.; Michael, M.; Rajput, H.; Patil, R.T. Dietary fibre in foods: A review. J. Food Sci. Technol. 2012, 49, 255-266. [CrossRef]

41. Fraga, C.G.; Croft, K.D.; Kennedy, D.O.; Tomás-Barberán, F.A. The effects of polyphenols and other bioactives on human health. Food Funct. 2019, 10, 514-528. [CrossRef] [PubMed]

42. Vetrani, C.; Costabile, G.; Vitale, M.; Giacco, R. (Poly)phenols and cardiovascular diseases: Looking in to move forward. J. Funct. Foods 2020, 71, 104013. [CrossRef]

43. Rasouli, H.; Farzaei, M.H.; Khodarahmi, R. Polyphenols and their benefits: A review. Int. J. Food Prop. 2017, 20, 1700-1741. [CrossRef]

44. Gowe, C. Review on Potential Use of Fruit and Vegetables By-Products as A Valuable Source of Natural Food Additives Some of the authors of this publication are also working on these related projects: Review on fruit and vegetables View project Review on Potential. Food Sci. Qual. Manag. 2015, 45, 47-61. 
45. Sagar, N.A.; Pareek, S. Fortification of multigrain flour with onion skin powder as a natural preservative: Effect on quality and shelf life of the bread. Food Biosci. 2021, 41, 100992. [CrossRef]

46. Taglieri, I.; Sanmartin, C.; Venturi, F.; Macaluso, M.; Bianchi, A.; Sgherri, C.; Quartacci, M.F.; De Leo, M.; Pistelli, L.; Palla, F.; et al Bread fortified with cooked purple potato flour and citrus albedo: An evaluation of its compositional and sensorial properties. Foods 2021, 10, 942. [CrossRef]

47. Durante, M.; Bleve, G.; Selvaggini, R.; Veneziani, G.; Servili, M.; Mita, G. Bioactive compounds and stability of a typical Italian bakery products "taralli" enriched with fermented olive paste. Molecules 2019, 24, 3258. [CrossRef]

48. Cedola, A.; Cardinali, A.; del Nobile, M.A.; Conte, A. Enrichment of Bread with Olive Oil Industrial By-Product. J. Agric. Sci. Technol. B 2019, 9, 119-127. [CrossRef]

49. AOAC International. Official Method of Analyisis, 17th ed.; AOAC International: Gaithersburg, MD, USA, 2006.

50. Caponio, F.; Difonzo, G.; Calasso, M.; Cosmai, L.; De Angelis, M. Effects of olive leaf extract addition on fermentative and oxidative processes of table olives and their nutritional properties. Food Res. Int. 2019, 116, 1306-1317. [CrossRef] [PubMed]

51. Difonzo, G.; Russo, A.; Trani, A.; Paradiso, V.M.; Ranieri, M.; Pasqualone, A.; Summo, C.; Tamma, G.; Silletti, R.; Caponio, F. Green extracts from Coratina olive cultivar leaves: Antioxidant characterization and biological activity. J. Funct. Foods 2017, 31, 63-70. [CrossRef]

52. Conte, P.; Pulina, S.; Del Caro, A.; Fadda, C.; Urgeghe, P.P.; De Bruno, A.; Difonzo, G.; Caponio, F.; Romeo, R.; Piga, A. Gluten-Free Breadsticks Fortified with Phenolic-Rich Extracts. Foods 2021, 10, 923. [CrossRef]

53. Difonzo, G.; Pasqualone, A.; Silletti, R.; Cosmai, L.; Summo, C.; Paradiso, V.M.; Caponio, F. Use of olive leaf extract to reduce lipid oxidation of baked snacks. Food Res. Int. 2018, 108, 48-56. [CrossRef] [PubMed]

54. Antónia Nunes, M.; Costa, A.S.G.; Bessada, S.; Santos, J.; Puga, H.; Alves, R.C.; Freitas, V.; Oliveira, M.B.P.P. Olive pomace as a valuable source of bioactive compounds: A study regarding its lipid- and water-soluble components. Sci. Total Environ. 2018, 644, 229-236. [CrossRef] [PubMed]

55. Cecchi, L.; Bellumori, M.; Cipriani, C.; Mocali, A.; Innocenti, M.; Mulinacci, N.; Giovannelli, L. A two-phase olive mill by-product (pâté) as a convenient source of phenolic compounds: Content, stability, and antiaging properties in cultured human fibroblasts J. Funct. Foods 2018, 40, 751-759. [CrossRef]

56. Simonato, B.; Trevisan, S.; Tolve, R.; Favati, F.; Pasini, G. Pasta fortification with olive pomace: Effects on the technological characteristics and nutritional properties. LWT 2019, 114, 108368. [CrossRef]

57. Difonzo, G.; Aresta, A.; Cotugno, P.; Ragni, R.; Squeo, G.; Summo, C.; Massari, F.; Pasqualone, A.; Faccia, M.; Zambonin, C.; et al. Supercritical CO2 Extraction of Phytocompounds from Olive Pomace Subjected to Different Drying Methods. Molecules 2021, 26, 598. [CrossRef]

58. European Commission. European Commission. Regulation (EC) No. 1169/2011 of the European Parliament and of the Council of 25 October 2011 on the Provision of Food Information to Consumers Amending Regulations (EC) No. 1924/2006 and (EC) No. 1925/2006 of the European Parliament. Available online: https:/ / eur-lex.europa.eu/LexUriServ/LexUriServ.do?uri=OJ:L:2011: 304:0018:0063:en:PDF (accessed on 23 November 2021).

59. Mudgil, D.; Barak, S. Classification, Technological Properties, and Sustainable Sources; Elsevier Inc.: New York, NY, USA, 2019; ISBN 9780128164952.

60. Gagneten, M.; Archaina, D.A.; Salas, M.P.; Leiva, G.E.; Salvatori, D.M.; Schebor, C. Gluten-free cookies added with fibre and bioactive compounds from blackcurrant residue. Int. J. Food Sci. Technol. 2021, 56, 1734-1740. [CrossRef]

61. Nakov, G.; Brandolini, A.; Hidalgo, A.; Ivanova, N.; Jukić, M.; Komlenić, D.K.; Lukinac, J. Influence of apple peel powder addition on the physico-chemical characteristics and nutritional quality of bread wheat cookies. Food Sci. Technol. Int. 2020, 26, 574-582. [CrossRef]

62. Mancebo, C.M.; Rodríguez, P.; Martínez, M.M.; Gómez, M. Effect of the addition of soluble (nutriose, inulin and polydextrose) and insoluble (bamboo, potato and pea) fibres on the quality of sugar-snap cookies. Int. J. Food Sci. Technol. 2018, 53, 129-136. [CrossRef]

63. Ribeiro, T.B.; Oliveira, A.; Coelho, M.; Veiga, M.; Costa, E.M.; Silva, S.; Nunes, J.; Vicente, A.A.; Pintado, M. Are olive pomace powders a safe source of bioactives and nutrients? J. Sci. Food Agric. 2021, 101, 1963-1978. [CrossRef]

64. Cedola, A.; Cardinali, A.; Del Nobile, M.A.; Conte, A. Fish burger enriched by olive oil industrial by-product. Food Sci. Nutr. 2017, 5, 837-844. [CrossRef]

65. Mir, S.A.; Bosco, S.J.D.; Shah, M.A.; Santhalakshmy, S.; Mir, M.M. Effect of apple pomace on quality characteristics of brown rice based cracker. J. Saudi Soc. Agric. Sci. 2017, 16, 25-32. [CrossRef]

66. Rainero, G.; Bianchi, F.; Rizzi, C.; Cervini, M.; Giuberti, G.; Simonato, B. Breadstick fortification with red grape pomace: Effect on nutritional, technological and sensory properties. J. Sci. Food Agric. 2021. [CrossRef] [PubMed]

67. Jahanbakhshi, R.; Ansari, S. Physicochemical Properties of Sponge Cake Fortified by Olive Stone Powder. J. Food Qual. 2020, 2020, 1493638. [CrossRef]

68. Miranda, D.V.; Rojas, M.L.; Pagador, S.; Lescano, L.; Sanchez-Gonzalez, J.; Linares, G. Gluten-Free Snacks Based on Brown Rice and Amaranth Flour with Incorporation of Cactus Pear Peel Powder: Physical, Nutritional, and Sensorial Properties. Int. J. Food Sci. 2018, 2018, 7120327. [CrossRef] [PubMed]

69. Markowicz, D.; Monaro, E.; Siguemoto, E.; Sefor, M. Maillard Reaction Products in Processed Food: Pros and Cons. In Food Industrial Processes-Methods and Equipment; InTech: London, UK, 2012.

70. Shen, Y.; Chen, G.; Li, Y. Bread characteristics and antioxidant activities of Maillard reaction products of white pan bread containing various sugars. LWT 2018, 95, 308-315. [CrossRef] 
71. Murata, M. Browning and pigmentation in food through the Maillard reaction. Glycoconj. J. 2021, 38, 283-292. [CrossRef]

72. Starowicz, M.; Zieliński, H. How Maillard Reaction Influences Sensorial Properties (Color, Flavor and Texture) of Food Products? Food Rev. Int. 2019, 35, 707-725. [CrossRef]

73. Liu, Y.X.; Cao, M.J.; Liu, G.M. Texture Analyzers for Food Quality Evaluation. In Evaluation Technologies for Food Quality; Elsevier Inc.: New York, NY, USA, 2019; pp. 441-463. ISBN 9780128142189.

74. Elgeti, D.; Jekle, M. Lipids in Gluten-Free Bread. Bak. Biscuit Int. 2015, 4, 88-92.

75. Duta, D.E.; Culetu, A. Evaluation of rheological, physicochemical, thermal, mechanical and sensory properties of oat-based gluten free cookies. J. Food Eng. 2015, 162, 1-8. [CrossRef]

76. Belorio, M.; Sahagún, M.; Gómez, M. Influence of Flour Particle Size Distribution on the Quality of Maize Gluten-Free Cookies. Foods 2019, 8, 83. [CrossRef] [PubMed]

77. Rocha-Parra, A.F.; Belorio, M.; Ribotta, P.D.; Ferrero, C.; Gómez, M. Effect of the particle size of pear pomace on the quality of enriched layer and sponge cakes. Int. J. Food Sci. Technol. 2019, 54, 1265-1275. [CrossRef]

78. Mancebo, C.M.; Picón, J.; Gómez, M. Effect of flour properties on the quality characteristics of gluten free sugar-snap cookies. LWT Food Sci. Technol. 2015, 64, 264-269. [CrossRef]

79. Saric, B.; Nedeljkovic, N.; Simurina, O.; Pestoric, M.; Kos, J.; Mandic, A.; Sakac, M.; Saric, L.; Psodorov, D.; Misan, A. The influence of baking time and temperature on characteristics of gluten free cookies enriched with blueberry pomace. Food Feed Res. 2014, 41, 39-46. [CrossRef]

80. Tsatsaragkou, K.; Protonotariou, S.; Mandala, I. Structural role of fibre addition to increase knowledge of non-gluten bread. J. Cereal Sci. 2016, 67, 58-67. [CrossRef]

81. Šarić, B.; Dapčević-Hadnađev, T.; Hadnađev, M.; Sakač, M.; Mandić, A.; Mišan, A.; Škrobot, D. Fiber concentrates from raspberry and blueberry pomace in gluten-free cookie formulation: Effect on dough rheology and cookie baking properties. J. Texture Stud. 2019, 50, 124-130. [CrossRef] [PubMed]

82. Föste, M.; Nordlohne, S.D.; Elgeti, D.; Linden, M.H.; Heinz, V.; Jekle, M.; Becker, T. Impact of quinoa bran on gluten-free dough and bread characteristics. Eur. Food Res. Technol. 2014, 239, 767-775. [CrossRef]

83. Raczyk, M.; Kruszewski, B.; Michałowska, D. Effect of Coconut and Chestnut Flour Supplementations on Texture, Nutritional and Sensory Properties of Baked Wheat Based Bread. Molecules 2021, 26, 4641. [CrossRef] [PubMed]

84. Martin-Diana, A.B.; Izquierdo, N.; Albertos, I.; Sanchez, M.S.; Herrero, A.; Sanz, M.A.; Rico, D. Valorization of Carob's Germ and Seed Peel as Natural Antioxidant Ingredients in Gluten-Free Crackers. J. Food Process. Preserv. 2017, 41, e12770. [CrossRef]

85. Caruso, M.C.; Galgano, F.; Colangelo, M.A.; Condelli, N.; Scarpa, T.; Tolve, R.; Favati, F. Evaluation of the oxidative stability of bakery products by OXITEST method and sensory analysis. Eur. Food Res. Technol. 2017, 243, 1183-1191. [CrossRef]

86. Pico, J.; Antolín, B.; Román, L.; Gómez, M.; Bernal, J. Analysis of volatile compounds in gluten-free bread crusts with an optimised and validated SPME-GC/QTOF methodology. Food Res. Int. 2018, 106, 686-695. [CrossRef] [PubMed]

87. O'Shea, N.; Kilcawley, K.N.; Gallagher, E. Aromatic composition and physicochemical characteristics of crackers containing barley fractions. Cereal Chem. 2017, 94, 611-618. [CrossRef]

88. Ludwig, V.; Berghetti, M.R.P.; Ribeiro, S.R.; Rossato, F.P.; Wendt, L.M.; Thewes, F.R.; Thewes, F.R.; Brackmann, A.; Both, V.; Wagner, R. The effects of soybean storage under controlled atmosphere at different temperatures on lipid oxidation and volatile compounds profile. Food Res. Int. 2021, 147, 110483. [CrossRef] [PubMed]

89. Gutiérrez-Del-río, I.; López-Ibáñez, S.; Magadán-Corpas, P.; Fernández-Calleja, L.; Pérez-Valero, Á.; Tuñón-Granda, M.; Miguélez, E.M.; Villar, C.J.; Lombó, F. Terpenoids and polyphenols as natural antioxidant agents in food preservation. Antioxidants 2021, 10, 1264. [CrossRef]

90. Rutkowska, J.; Antoniewska, A.; Martinez-Pineda, M.; Nawirska-Olszańska, A.; Zbikowska, A.; Baranowski, D. Black Chokeberry Fruit Polyphenols: A Valuable Addition to Reduce Lipid Oxidation of Muffins Containing Xylitol. Antioxidants 2020, 9, 394. [CrossRef] [PubMed]

91. Giarnetti, M.; Paradiso, V.M.; Caponio, F.; Summo, C.; Pasqualone, A. Fat replacement in shortbread cookies using an emulsion filled gel based on inulin and extra virgin olive oil. LWT 2015, 63, 339-345. [CrossRef]

92. Pico, J.; Bernal, J.; Gómez, M. Wheat bread aroma compounds in crumb and crust: A review. Food Res. Int. 2015, 75, 200-215. [CrossRef]

93. Delgado, R.M.; Hidalgo, F.J.; Zamora, R. Antagonism between lipid-derived reactive carbonyls and phenolic compounds in the Strecker degradation of amino acids. Food Chem. 2016, 194, 1143-1148. [CrossRef]

94. Pasqualone, A.; Caponio, F.; Pagani, M.A.; Summo, C.; Paradiso, V.M. Effect of salt reduction on quality and acceptability of durum wheat bread. Food Chem. 2019, 289, 575-581. [CrossRef]

95. Whetstine, M.E.C.; Drake, M.A.; Broadbent, J.R.; McMahon, D. Enhanced nutty flavor formation in cheddar cheese made with a malty Lactococcus lactis adjunct culture. J. Dairy Sci. 2006, 89, 3277-3284. [CrossRef]

96. Gong, Y.; Kerrihard, A.L.; Pegg, R.B. Characterization of the Volatile Compounds in Raw and Roasted Georgia Pecans by HS-SPME-GC-MS. J. Food Sci. 2018, 83, 2753-2760. [CrossRef] [PubMed]

97. Cherfaoui, M.; Cecchi, T.; Keciri, S.; Boudriche, L. Volatile compounds of algerian extra-virgin olive oils: Effects of cultivar and ripening stage. Int. J. Food Prop. 2018, 21, 36-49. [CrossRef]

98. Cortés-Delgado, A.; Sánchez, A.H.; de Castro, A.; López-López, A.; Beato, V.M.; Montaño, A. Volatile profile of Spanish-style green table olives prepared from different cultivars grown at different locations. Food Res. Int. 2016, 83, 131-142. [CrossRef] 
99. Flamini, G.; Cioni, P.L.; Morelli, I. Volatiles from leaves, fruits, and virgin oil from Olea europaea cv. Olivastra Seggianese from Italy. J. Agric. Food Chem. 2003, 51, 1382-1386. [CrossRef] [PubMed]

100. Maatallah, S.; Dabbou, S.; Castagna, A.; Guizani, M.; Hajlaoui, H.; Ranieri, A.M.; Flamini, G. Prunus persica by-products: A source of minerals, phenols and volatile compounds. Sci. Hortic. 2020, 261, 109016. [CrossRef]

101. Lee, S.M.; Zheng, L.W.; Jung, Y.; Hwang, G.S.; Kim, Y.S. Effects of hydroxycinnamic acids on the reduction of furan and $\alpha$-dicarbonyl compounds. Food Chem. 2020, 312, 126085. [CrossRef] [PubMed]

102. Mildner-Szkudlarz, S.; Siger, A.; Szwengiel, A.; Przygoński, K.; Wojtowicz, E.; Zawirska-Wojtasiak, R. Phenolic compounds reduce formation of $\mathrm{N} \varepsilon$-(carboxymethyl)lysine and pyrazines formed by Maillard reactions in a model bread system. Food Chem. 2017, 231, 175-184. [CrossRef]

103. Zheng, L.W.; Chung, H.; Kim, Y.S. Effects of dicarbonyl trapping agents, antioxidants, and reducing agents on the formation of furan and other volatile components in canned-coffee model systems. Food Res. Int. 2015, 75, 328-336. [CrossRef]

104. Jansson, T.; Rauh, V.; Danielsen, B.P.; Poojary, M.M.; Waehrens, S.S.; Bredie, W.L.P.; Sørensen, J.; Petersen, M.A.; Ray, C.A.; Lund, M.N. Green Tea Polyphenols Decrease Strecker Aldehydes and Bind to Proteins in Lactose-Hydrolyzed UHT Milk. J. Agric. Food Chem. 2017, 65, 10550-10561. [CrossRef]

105. Ou, J.; Wang, M.; Zheng, J.; Ou, S. Positive and negative effects of polyphenol incorporation in baked foods. Food Chem. 2019, $284,90-99$. [CrossRef] [PubMed]

106. Hidalgo, F.J.; Aguilar, I.; Zamora, R. Model Studies on the Effect of Aldehyde Structure on Their Selective Trapping by Phenolic Compounds. J. Agric. Food Chem. 2017, 65, 4736-4743. [CrossRef] [PubMed]

107. Mildner-Szkudlarz, S.; Różańska, M.; Piechowska, P.; Waśkiewicz, A.; Zawirska-Wojtasiak, R. Effects of polyphenols on volatile profile and acrylamide formation in a model wheat bread system. Food Chem. 2019, 297, 125008. [CrossRef] [PubMed]

108. Cecchi, L.; Schuster, N.; Flynn, D.; Bechtel, R.; Bellumori, M.; Innocenti, M.; Mulinacci, N.; Guinard, J. Sensory Profiling and Consumer Acceptance of Pasta, Bread, and Granola Bar Fortified with Dried Olive Pomace (Pâté): A Byproduct from Virgin Olive Oil Production. J. Food Sci. 2019, 84, 2995-3008. [CrossRef]

109. Johnson, R.L.; Mitchell, A.E. Reducing Phenolics Related to Bitterness in Table Olives. J. Food Qual. 2018, 2018, 3193185. [CrossRef]

110. Pedan, V.; Popp, M.; Rohn, S.; Nyfeler, M.; Bongartz, A. Characterization of phenolic compounds and their contribution to sensory properties of olive oil. Molecules 2019, 24, 41. [CrossRef] [PubMed]

111. Huang, R.; Xu, C. An overview of the perception and mitigation of astringency associated with phenolic compounds. Compr. Rev. Food Sci. Food Saf. 2021, 20, 1036-1074. [CrossRef] [PubMed] 